\title{
Kliničke i biokemijske značajke pretilosti u pacijenata sa shizofrenijom
}

\section{Clinical and biochemical features of obesity in patients with schizophrenia}

\author{
Sergej Nadalin ${ }^{1^{*}}$, Jelena Rebić ${ }^{2}$, Klementina Ružić ${ }^{2}$ Kristina Ilinović3 ${ }^{3}$ Vesna Šendula Jengić4, \\ Vjekoslav Peitt ${ }^{5}$, Dalibor Karlovićs, Alena Buretić-Tomljanović ${ }^{1}$
}

\begin{abstract}
${ }^{1}$ Zavod za medicinsku biologiju i genetiku, Medicinski fakultet Sveučilišta u Rijeci

${ }^{2}$ Klinika za psihijatriju, Klinički bolnički centar Rijeka

${ }^{3}$ Fakultet zdravstvenih studija Sveučilišta u Rijeci

${ }^{4}$ Psihijatrijska bolnica Rab

${ }^{5}$ Klinika za psihijatriju, Klinički bolnički centar Sestre milosrdnice i Hrvatsko katoličko sveučilište
\end{abstract}

\section{"Dopisni autor:}

Doc. dr. sc. Sergej Nadalin, dr. med. Zavod za medicinsku biologiju i genetiku, Medicinski fakultet Sveučilišta u Rijeci e-mail: sergej.nadalin@medri.uniri.hr

http://hrcak.srce.hr/medicina
Sažetak. Cilj: Istražili smo povezanost pojave pretilosti s kliničkim značajkama shizofrenije, poput dobi, trajanja bolesti, dobi nastupa bolesti, ovisnosti o pušenju i težine simptoma ocjenske ljestvice PANSS-a (engl. Positive and Negative Syndrome Scale - PANSS). Također smo testirali doprinos pretilosti biokemijskim parametrima: koncentracijama ukupnog kolesterola, LDL kolesterola (engl. low density lipoprotein cholesterol), HDL kolesterola (engl. high density lipoprotein cholesterol), triglicerida i glukoze u plazmi. Ispitanici i metode: $\mathrm{U}$ istraživanju su sudjelovala 142 kronična pacijenta sa shizofrenijom. Pretilim pacijentima smatrani su oni s vrijednostima indeksa tjelesne mase (ITM) $>30$, dok su pacijenti s normalnom tjelesnom masom (ITM: 20 - 25) i pacijenti s prekomjernom tjelesnom masom (ITM: 25 - 30) klasificirani u nepretile. Rezultati: Nije uočena statistički značajna povezanost pretilosti s kliničkim značajkama $(P>0,05)$. Koncentracije ukupnog kolesterola i LDL kolesterola bile su značajno više u pretilih pacijentica u odnosu na nepretile pacijentice, dok su značajno više vrijednosti triglicerida uočene kod pretilih u odnosu na nepretile ispitanike oba spola $(P<0,05)$. Ipak, samo se trajanje bolesti pokazalo značajnim prediktorom vrijednosti triglicerida u pacijentica, dok je učinak pretilosti ostao izvan statističke značajnosti $(P>0.05)$. Pojava pretilosti opisuje približno $8,3 \%$ varijabilnosti koncentracija triglicerida u muškaraca te $9,6 \%$ i $13,8 \%$ varijabilnosti koncentracija ukupnog kolesterola i LDL kolesterola u žena. Zaključak: Pretilost pridonosi isključivo biokemijskim parametrima u pacijenata sa shizofrenijom. U muškaraca determinira vrijednosti triglicerida, a u žena koncentracije ukupnog kolesterola i LDL kolesterola te opisuje približno 8,3-13,8\% varijabilnosti njihove koncentracije.

Ključne riječi: indeks tjelesne mase; pretilost; shizofrenija

Abstract. Aim: We investigated the association between obesity and clinical characteristics of schizophrenia, such as age, illness duration, age of illness onset, nicotine dependence and clinical psychopathology measured via Positive and Negative Syndrome Scale scores. We also tested whether obesity contributes to biochemical parameters: plasma total cholesterol, LDL cholesterol (low density lipoprotein cholesterol), HDL cholesterol (high density lipoprotein cholesterol), and triglyceride and glucose levels. Patients and methods: Our study group consisted of 142 chronically ill patients with schizophrenia. Patients were classified as obese with body mass index (BMI) values $>30$, and non-obese, those who were overweight (BMI: $25-30$ ), or those having a normal body weight (BMI: < 25). Results: We did not find statistically significant associations between obesity and clinical characteristics $(P>0.05)$. Plasma total cholesterol and LDL concentrations were significantly higher in obese females compared to non-obese females, and significantly greater plasma triglyceride values were observed among obese patients of both genders compared to non-obese $(P<0.05)$. However, only the illness duration significantly predicted triglyceride concentration in females, whereas the influence of obesity on triglyceride levels did not reach significance $(P$ $>0.05$ ). The obesity accounts for approximately $8.3 \%$ variability of triglyceride values in males and $9.6 \%$ and $13.8 \%$ of total cholesterol and LDL cholesterol variability in females. 
Conclusion: The obesity significantly contributes only to biochemical parameters in patients with schizophrenia. In males, it determines triglyceride values, whereas in females, it underlies total cholesterol and LDL cholesterol levels, accounting for approximately $8.3-13.8 \%$ of their variability.

Key words: body mass index; obesity; schizophrenia

\section{UVOD}

Shizofrenija je udružena s visokom stopom pretilosti, koja prema literaturnim podacima iznosi 45 $55 \%$ za zapadnjačke populacije, što je približno 2 - 3 puta više negoli u općoj populaciji ${ }^{1,2}$. Vjeruje se da je etiologija pretilosti u shizofreniji multifaktorska; glavnim okolišnim čimbenicima podložnosti smatraju se antipsihotični lijekovi i nezdrava prehrana ${ }^{3,4}$. Istraživanja su pokazala da inhibicija neurotransmiterskih sustava antipsihoticima, osim što opušta i smanjuje tjelesnu aktivnost, smanjuje učinak hormona sitosti - leptina na unos hrane, što potiče sekreciju leptina, razvoj rezistencije na leptin i stimulira apetit ${ }^{5-7}$. Nadalje, pojedini antipsihotici povisuju koncentraciju neuropeptida $Y$, za koji je poznato da, također, potiče hranjenje ${ }^{7-9}$. Pojačano stanje upalnog odgovora, implicirano u etiologiji pretilosti te njenim komplikacijama, poput rezistencije na inzulin i metaboličkog sindroma, u shizofreniji se često povezuje s nezdravom prehranom ${ }^{10-13}$. Uočeno je da pacijenti unose značajno manje vlakana, folata, polinezasićenih masnih kiselina (engl. Polyunsaturated fatty acid - PUFA), posebice n-3 PUFA, kao i mononezasićenih masnih kiselina (engl. Monounsaturated fatty acid MUFA), a više zasićenih masnoća i kalorija ${ }^{6,14,15}$. Poznato je da zasićene masne kiseline (engl. Saturated fatty acid - SFA) potiču nastanak upalnog odgovora, dok MUFA i pojedini metaboliti n-3 PUFA suzbijaju upalne procese ${ }^{6,16-18}$ Inače, nezdrav način prehrane i smanjena tjelesna aktivnost češće su opaženi u pacijenata s predominacijom negativnih simptoma bolesti, višim stupnjem kognitivnih disfunkcija, kao i onih koji se nezaposleni, negativnog bračnog statusa i lošijeg socioekonomskog statu$\mathrm{sa}^{19,20}$. Konačno, važnu bi ulogu u etiologiji pretilosti u shizofreniji mogli imati genetički čimbenici; poseban se značaj pripisuje genima koji se povezuju $\mathrm{s}$ porastom tjelesne mase nakon terapije antipsihoticima, poput gena za alfa-adrenergičku transmisiju, zatim gena uključenih u signalne puteve leptina, hormona gladi - grelina te gena za neurotransmiterske sustave, kao što su gen za dopaminski receptor D2 i serotoninski receptor HTR2C (engl. 5-hydroxytryptamine receptor $2 \mathrm{C})^{20-21}$.

Istraživanje fenomena pretilosti u shizofreniji predstavlja javnozdravstveni, ali i farmakoterapijski značaj. Naime, pretilost, posebice visceralna (abdominalna), glavni je čimbenik rizika za obolijevanje od metaboličkog sindroma i kardiovaskularnih bolesti, a poznato je da kardiovaskularna

Ispitali smo povezanost pojave pretilosti s kliničkim značajkama shizofrenije, kao što su dob, trajanje bolesti, dob nastupa bolesti, ovisnost o pušenju i težina kliničke slike. Također smo istražili pridonosi li pretilost biokemijskim parametrima, poput koncentracija ukupnog kolesterola, LDL kolesterola, HDL kolesterola, triglicerida i glukoze u plazmi.

oboljenja, nakon visoke stope samoubojstava, najviše pridonose skraćenom životnom vijeku u pacijenata sa shizofrenijom ${ }^{1,6,22}$. Unatoč tome što su čimbenici rizika i potencijalni patogenetski mehanizmi za pretilost u shizofreniji dobro opisani u literaturi, jako je malo istraživanja koja su sustavno ispitala obilježja fenomena pretilosti u shizofreniji, odnosno, istražila postoji li povezanost između kliničkih i biokemijskih značajki shizofrenije s pojavom pretilosti; među njima, najveći je broj studija uključio pacijente iz kineske populacije 2,23-27. Istraživanja u kineskoj populaciji upućuju na pozitivnu povezanost indeksa tjelesne mase (ITM) s koncentracijama triglicerida, ukupnog kolesterola, LDL kolesterola (engl. low density lipoprotein cholesterol), glukoze i malonaldehida u plazmi te s rizikom za obolijevanje od dijabetesa tipa 2. S druge strane, ITM se pokazao negativnim prediktorom koncentracija HDL kolesterola (engl. high density lipoprotein cholesterol), intenziteta ovisnosti o pušenju, koji je determiniran kroz prosječan broj popušenih cigareta dnevno, kao i težine negativnih, općih i ukupnih simptoma PANSS-a (engl. Positive and Negative Syndrome Scale), iako se rezultati razlikuju za pojedine studije ${ }^{2,25-27}$. Istraživanja povezanosti ITM-a s kognitivnim funkcijama u kineskoj 
populaciji rezultirala su neujednačenim spoznajama: opažen je veći stupanj različitih kognitivnih disfunkcija (deficit pažnje, kognitivnog procesiranja i egzekutivnog funkcioniranja, slabija sposobnost učenja, pamćenja i dr.) u pretilih pacijenata sa shizofrenijom u odnosu na nepretile, ali i protektivan učinak viših vrijednosti ITM-a na kognitivne simptome PANSS psihopatologije ${ }^{23}$. U istraživanju, u kojem su analize napravljene zasebno u spolova, pronađene su značajno niže vrijednosti negativnih i ukupnih simptoma PANSS-a te više vrijednosti triglicerida u plazmi u pretilih muškaraca u usporedbi s nepretilima, dok su u žena, povezano s pojavom pretilosti, zamijećene korelacije isključivo s biokemijskim parametrima; pretile su pacijentice, u odnosu na nepretile, obolijevale češće od dijabetesa tipa 2 i imale više vrijednosti triglicerida u plazmi ${ }^{25}$. U nedavno istraživanje kliničkih i biokemijskih značajki pretilosti, provedeno u sjevernoameričkoj populaciji, osim pacijenata sa shizofrenijom i shizoafektivnim poremećajem, uključeni su pacijenti s bipolarnim afektivnim poremećajem ${ }^{24}$. U pacijenata $\mathrm{S}$ prekomjernom tjelesnom masom i pretilosti opažena je značajno veća učestalost shizoafektivnog poremećaja negoli shizofrenije i bipolarnog afektivnog poremećaja, veći broj depresivnih epizoda, izraženije suicidalno ponašanje, veći broj hospitalizacija, kao i veća učestalost dijabetesa tipa 2, dislipidemija i hipertenzije.

Istraživanje provedeno u hrvatskih muškaraca sa shizofrenijom ( $N=101$ ) ukazuje na visoku učestalost pretilosti koja iznosi $22 \%{ }^{28}$. Nadalje, studije na kroničnim pacijentima sa shizofrenijom $\mathrm{u} \mathrm{hr}$ vatskoj populaciji pokazale su da gotovo $100 \%$ oboljelih uzima atipične antipsihotike, posebice klozapin i olanzapin ${ }^{28,29}$ koji se povezuju s najvećim rizikom za pretilost ${ }^{7}$. Također je opaženo da visok postotak oboljelih od shizofrenije u hrvatskoj populaciji puši (muškarci: 69 - 71 \%; žene: 46 - $61 \%)^{29,30}$, a literaturni podaci upućuju i na pušenje kao modulator pretilosti2,24. Kako bi se razvile odgovarajuće preventivne mjere vezane uz pretilost u shizofreniji, potrebno je bolje razumijevanje kliničkih i biokemijskih implikacija pretilosti. Pregledavanjem znanstvene literature nismo pronašli studiju koja je istražila kliničke i biokemijske korelate pretilosti u hrvatskoj ili europskoj populaciji pacijenata sa shizofrenijom. U skladu s time, u ovom smo istraživanju ispitali postoji li povezanost pojave pretilosti, determinirane kroz vrijednosti ITM-a, s kliničkim značajkama shizofrenije (dob, trajanje bolesti, dob nastupa bolesti, ovisnost o pušenju i težina simptoma ocjenske ljestvice PANSS-a) te s biokemijskim parametrima (koncentracije lipida i glukoze u plazmi), u skupini pacijenata u hrvatskoj populaciji. Pretpostavili smo veću učestalost pretilosti na uzorku hrvatskih pacijenata sa shizofrenijom u odnosu sa njenu učestalost u općoj hrvatskoj populaciji. Nadalje, očekujemo da bi, kao što je opisano u literaturi, pretilost mogla istovremeno predstavljati rizičan čimbenik za biokemijske parametre, a protektivan čimbenik za težinu simptoma PANSS psihopatologije 2,23-27. Konačno, moguće je da učestalost pretilosti pokazuje varijacije ovisno o dobi, trajanju bolesti, dobi nastupa bolesti, kao i učestalosti ovisnosti o pušenju. S obzirom na to da literaturni podaci upućuju na različitu učestalost i korelate pretilosti s obzirom na spol ${ }^{2,25}$, sve smo analize napravili zasebno u pacijenata i pacijentica.

\section{ISPITANICI I METODE}

U istraživanju su sudjelovala 142 kronična pacijenta $s$ dijagnozom shizofrenije utvrđenom prema DSM-IV klasifikaciji uz korištenje strukturiranog kliničkog intervjua (engl. Structured clinical interview - SCID) koji su bili hospitalizirani na Klinici za psihijatriju Kliničkog bolničkog centra Rijeka ( $N=120)$ i Psihijatrijskoj bolnici Rab ( $N=22$ ). Klinička praksa je da se svi pacijenti najprije obrađuju u Kliničkom bolničkom centru Rijeka, a zatim se, ako postoji potreba za produženim liječenjem, upućuju u Psihijatrijsku bolnicu Rab. Pacijenti su prikupljani u periodu od 2013. do 2018. godine za genetičke analize u okviru nekoliko znanstvenoistraživačkih projekata (potpora). Njihove demografske i kliničke značajke prikazane su u tablici 1. Istraživanje je provedeno u skladu s najnovijom revizijom Helsinške deklaracije, a uz potporu Etičkih povjerenstava Kliničkog bolničkog centra Rijeka, Psihijatrijske bolnice Rab i Medicinskog fakulteta u Rijeci. Svi pacijenti koji su sudjelovali u istraživanju kontinuirano su uzimali antipsihotike; otprilike dvije trećine pacijenata 
bilo je na politerapiji, a trećina pacijenata na monoterapiji. Dob prve hospitalizacije zbog psihotičnog ponašanja tijekom koje je postavljena dijagnoza shizofrenije uzeta je u obzir kao približna dob nastupa bolesti. U akutnoj fazi bolesti, tijekom posljednje hospitalizacije, specijalisti psihijatri napravili su evaluaciju simptoma ocjenske ljestvice PANSS psihopatologije, prikupili podatke vezane za ovisnost o pušenju, a napravljeno je i određivanje ITM-a. Ocjenska ljestvica PANSS-a sastoji se od 30 čestica od kojih 7 mjeri pozitivne simptome, 7 je za negativne simptome, te 16 za opće simptome, koji obuhvaćaju kognitivne simptome (smetnje pozornosti, pamćenja i apstraktnog mišljenja) i afektivne simptome (simptome promijenjenog raspoloženja). Ukupni simptomi ocjenske ljestvice PANSS psihopatologije predstavljaju zbroj vrijednosti svih pozitivnih, negativnih i općih simptoma ${ }^{31}$. U pušače su klasificirani ispitanici koji puše najmanje jednu cigaretu dnevno dulje od godine dana, a u nepušače ispitanici koji su popušili manje od 100 cigareta tijekom života $^{32,33}$. Za veći broj pacijenata nisu postojali podaci o težini ovisnosti o pušenju (broj popušenih cigareta dnevno, ili broj cigareta dnevno $x$ godine pušenja), stoga je u obzir uzeto isključivo je li pacijent pušač ili nepušač. Na temelju podataka o tjelesnoj masi $(\mathrm{kg})$ i visini $(\mathrm{m})$, izračunate su vrijednosti ITM-a $\left(\mathrm{kg} / \mathrm{m}^{2}\right)$; u pretile pacijente klasificirani su oni s vrijednostima ITM-a > 30. Pacijenti $s$ normalnom tjelesnom masom (ITM vrijednosti od 20 do 25) i pacijenti s prekomjernom tjelesnom masom (ITM vrijednosti od 25 do 30) klasificirani su kao nepretili ${ }^{34,35}$. Plazmatske koncentracije različitih vrsta lipida (ukupni kolesterol, LDL kolesterol, HDL kolesterol, trigliceridi) i glukoze određene su natašte, nakon cjelonoćnog gladovanja, pomoću biokemijskog analizatora Olympus (AU 640, Tokio, Japan). Vrijednosti (u mmol/L) ukupnog kolesterola > 5,0, LDL kolesterola $>3,0$, triglicerida $>2,0$ i glukoze $>6,1$ smatrane su povišenima, a HDL kolesterola $<1,0$ sniženima, za hrvatsku populaciju ${ }^{36,37}$.

\section{Statistička analiza}

Kao mjere središnjice i raspršenja korištene su aritmetička sredina i standardna devijacija. Korištenjem hi-kvadrat $\left(\chi^{2}\right)$ testa ispitana je razlika u učestalosti pojave pretilosti i učestalosti ovisnosti o pušenju između spolova. Pomoću jednosmjernog ANOVA testa ispitane su razlike u vrijednostima kliničkih i biokemijskih parametara između pretilih i nepretilih muškaraca i žena. Izračunata je veličina uzorka $(\alpha=0,05, \beta=0,80)$ za dvije skupine ispitanika za jednosmjerni ANOVA test $(\mathrm{N}=$ 127). Korištenjem dviju multiplih regresijskih analiza testirali smo u kojoj mjeri pretilost pridonosi opaženim varijacijama biokemijskih parametara; u obje regresijske analize među nezavisne

Rezultati istraživanja pokazuju da je pojava pretilosti značajni prediktor prvenstveno biokemijskih parametara u pacijenata sa shizofrenijom, kao i da se učinak pretilosti na biokemijske parametre razlikuje između muškaraca i žena. U muškaraca, pored dužine trajanja bolesti, pretilost značajno determinira vrijednosti triglicerida, a u žena, vrijednosti ukupnog kolesterola i LDL kolesterola.

varijable (prediktore) uključili smo trajanje bolesti, a u prvu regresijsku analizu, koja je napravljena na ukupnom uzorku pacijenata među prediktore je uvršten i spol ispitanika. U obradi podataka korišten je računalni program Statistica for Windows, inačica 13 (StratSoft, Inc. Tulsa, OK, USA), a $P$ vrijednosti koje su iznosile manje od $0,05(P<0,05)$ smatrane su statistički značajnima.

\section{REZULTATI}

Sedamnaest od 64 muškarca $(26,6 \%)$ i 23 od 78 žena $(29,5 \%)$ je pretilo, što upućuje na veću učestalost pretilosti u odnosu na onu opaženu u općoj populaciji Republike Hrvatske ${ }^{34}$, kao i u odnosu na učestalost koja je pronađena u nedavnom istraživanju u hrvatskih muškaraca sa shizofrenijom $^{34}$. Prema srednjim vrijednostima ITM-a, ispitanici oba spola imaju prekomjernu tjelesnu masu $^{34,35}$. Koncentracije ukupnog kolesterola i LDL kolesterola u žena te triglicerida u muškaraca neznatno su više u odnosu na referentne vrijednosti (tablica 1$)^{36,37}$.

Nije opažena značajna razlika u dobi, trajanju bolesti, dobi nastupa bolesti, učestalosti ovisnosti o pušenju i vrijednostima simptoma PANSS psihopatologije ovisno o pojavi pretilosti, niti u muška- 
Tablica 1. Demografske i kliničke značajke ispitanika

\begin{tabular}{|l|c|c|c|}
\cline { 2 - 3 } \multicolumn{1}{c|}{} & Muškarci (N = 64) & Žene (N = 78) & \multicolumn{1}{c|}{} \\
\hline Dob (godine) & $40,3 \pm 10,7$ & $44,4 \pm 11,0$ & 0,021 \\
\hline Trajanje bolesti (godine) & $13,3 \pm 9,4$ & $16,8 \pm 11,2$ & 0,054 \\
\hline Dob prve hospitalizacije & $27,0 \pm 7,9$ & $27,6 \pm 8,4$ & 0,642 \\
\hline Zbroj pozitivnih simptoma PANSS-a & $26,8 \pm 4,8$ & $24,0 \pm 5,5$ & 0,010 \\
\hline Zbroj negativnih simptoma PANSS-a & $29,2 \pm 6,1$ & $28,2 \pm 7,3$ & 0,469 \\
\hline Zbroj općih simptoma PANSS-a & $53,3 \pm 7,5$ & $50,1 \pm 8,9$ & 0,061 \\
\hline Zbroj ukupnih simptoma PANSS-a & $109,2 \pm 13,7$ & $102,2 \pm 16,9$ & 0,031 \\
\hline Ovisnost o pušenju (pušači/nepušači) & $47 / 17$ & $54 / 24$ & 0,582 \\
\hline Ukupni kolesterol & $4,8 \pm 1,1$ & $5,2 \pm 1,1$ & 0,097 \\
\hline LDL kolesterol & $3,0 \pm 1,0$ & $3,3 \pm 0,9$ & 0,176 \\
\hline HDL kolesterol & $1,1 \pm 0,2$ & $1,3 \pm 0,4$ & $<0,001$ \\
\hline Trigliceridi & $2,2 \pm 1,3$ & $1,6 \pm 0,7$ & $<0,001$ \\
\hline Glukoza & $5,6 \pm 0,6$ & $6,0 \pm 1,1$ & 0,019 \\
\hline Indeks tjelesne mase & $26,9 \pm 3,8$ & $26,7 \pm 5,5$ & 0,803 \\
\hline Nepretili/pretili & $47 / 17$ & $55 / 23$ & 0,700 \\
\hline
\end{tabular}

raca, niti u žena $(P>0,05)$, a od biokemijskih parametara samo su se koncentracije kolesterola i triglicerida razlikovale između pretilih i nepretilih ispitanika (tablica 2). Koncentracije ukupnog kolesterola i LDL kolesterola bile su značajno više $\mathrm{u}$ pretilih pacijentica $\mathrm{u}$ odnosu na nepretile pacijentice $(5,7 \pm 1,1$, vs. $5,0 \pm 1,0 ; 3,8 \pm 1,0$ vs. $3,0 \pm$ $0,8 ; P<0,05)$, a značajno više vrijednosti triglicerida uočene su kod pretilih u odnosu na nepretile ispitanike oba spola (muškarci: $2,8 \pm 1,5$ vs. 1,9 \pm $1,2, P<0,05$; žene: $1,8 \pm 0,8$ vs. $1,4 \pm 0,6, P<$ $0,05)$.

Multipla regresijska analiza na ukupnom uzorku pacijenata pokazala je da je pretilost statistički značajan prediktor koncentracija ukupnog kolesterola, LDL kolesterola i triglicerida te da opisuje približno 7,3 \%, 8,1 \% i 6,2 \% njihove varijabilnosti (promjena $R^{2}=0,073,0,081$ i 0,062) (tablica 3). Uz pretilost, značajnim prediktorom koncentracije triglicerida, pokazali su se spol, koji u najvećoj mjeri pridonosi varijabilnostima vrijednosti triglicerida (promjena $\mathrm{R}^{2}=0,104$ ) i trajanje bolesti, čiji je učinak na koncentracije triglicerida nešto manji negoli učinak pretilosti (promjena $\mathrm{R}^{2}=$ 0,048 vs. 0,062 ). Analiza u spolova pokazala je da pretilost pridonosi vrijednostima triglicerida $\mathrm{u}$ muškaraca $\mathrm{s}$ približno $8,3 \%$ (promjena $\mathrm{R}^{2}=$ $0,083)$, dok je učinak pretilosti na vrijednosti triglicerida u žena ostao izvan statističke značajnosti
$(P>0,05)$ te su one pokazale povezanost isključivo $s$ trajanjem bolesti, koja opisuje približno 24,3\% njihove varijabilnosti (promjena $R^{2}=$ 0,243 ) (tablica 4). Nadalje, pretilost je jedini značajan prediktor koncentracija ukupnog kolesterola i LDL kolesterola u pacijentica te pridonosi $\mathrm{s}$ približno $9,6 \%$ i $13,8 \%$ varijabilnostima njihove koncentracije (promjena $R^{2}=0,096$ i 0,138).

\section{RASPRAVA I ZAKLJUČAK}

U ovom istraživanju, koje je prvo takve vrste u hrvatskoj populaciji, ispitali smo povezanost pretilosti s kliničkim značajkama shizofrenije, kao što su dob, trajanje bolesti, dob nastupa bolesti, težina simptoma ocjenske ljestvice PANSS-a i ovisnost o pušenju. Također nas je zanimalo postoji li povezanost između biokemijskih parametara, poput koncentracija ukupnog kolesterola, LDL kolesterola, HDL kolesterola, triglicerida i glukoze u plazmi, s pojavom pretilosti u pacijenata. Rezultati istraživanja ukazuju da je pretilost statistički značajan prediktor isključivo biokemijskih parametara u pacijenata sa shizofrenijom, kao i da se učinak pretilosti na istražene biokemijske parametre razlikuje između muškaraca i žena (tablice 2, 3 i 4).

Nepostojanje značajne povezanosti između pretilosti, dobi ispitanika i dobi nastupa bolesti uklapa se $u$ rezultate opisane $u$ literaturi (tablica 2) 2,24-27. 
Tablica 2. Klinički i biokemijski parametri u nepretilih i pretilih muškaraca $(N=64)$ i žena $(N=78)$

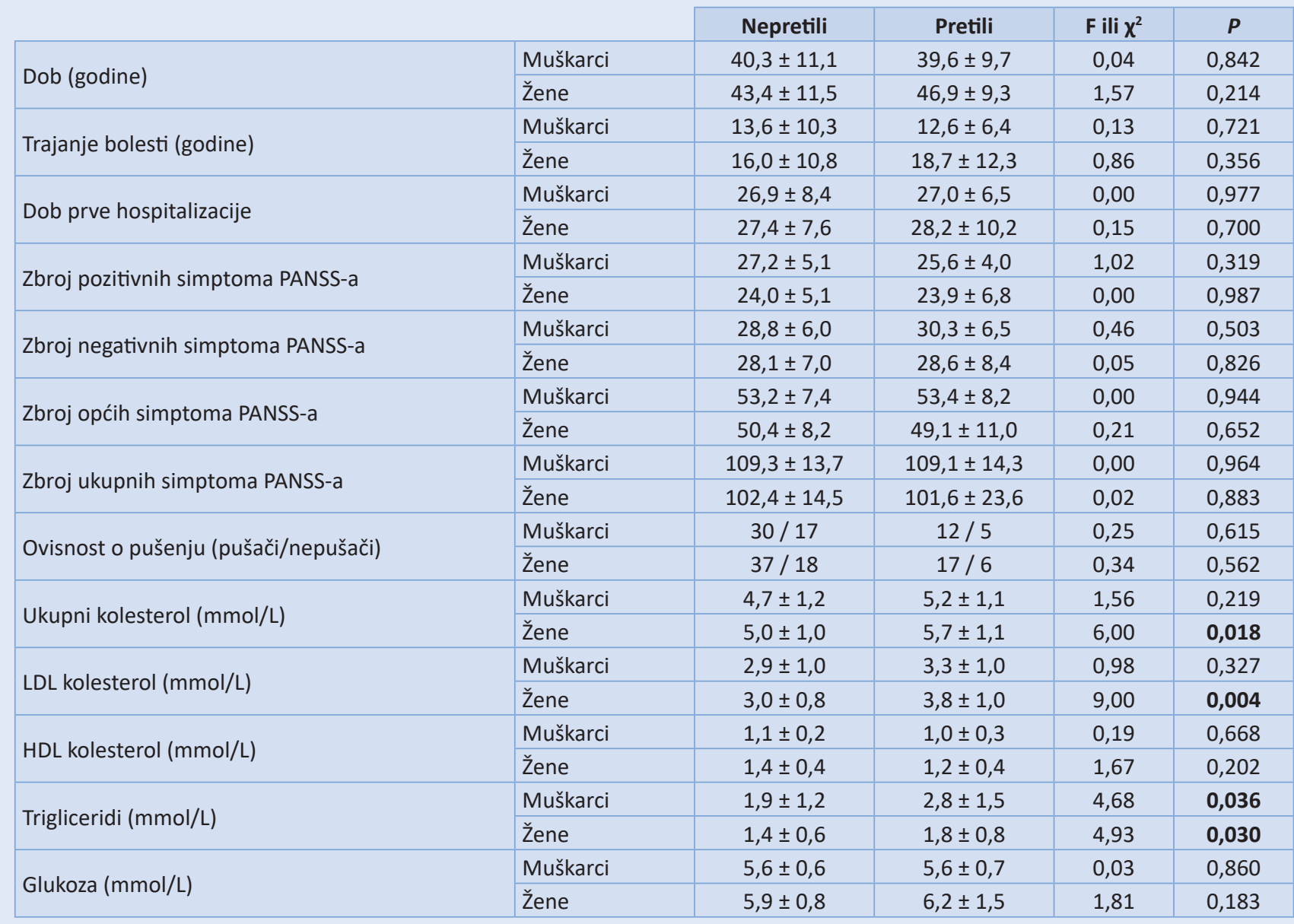

Tablica 3. Koncentracije lipida u odnosu na trajanje bolesti, pretilost i spol na ukupnom uzorku pacijenata

\begin{tabular}{|c|c|c|c|c|c|}
\hline Zavisna varijabla & Nezavisna varijabla & b & Promjena $^{\mathbf{2}}$ & $\mathbf{F}^{\mathbf{b}}$ & $\boldsymbol{P}^{\mathbf{2}}$ \\
\hline ukupni kolesterol & pretilost & 0,27 & 0,073 & $\mathbf{7 , 1 8}$ & $\mathbf{0 , 0 0 9}$ \\
\hline LDL kolesterol & pretilost & 0,29 & 0,081 & 8,03 & $\mathbf{0 , 0 0 6}$ \\
\hline \multirow{2}{*}{ trigliceridi } & spol & $-0,38$ & 0,104 & 13,25 & $<\mathbf{0 , 0 0 1}$ \\
\hline & pretilost & 0,24 & 0,062 & 8,46 & $\mathbf{0 , 0 0 4}$ \\
\hline & trajanje bolesti & 0,22 & 0,048 & 4,85 & $\mathbf{0 , 0 1 0}$ \\
\hline
\end{tabular}

a nezavisne varijable: pretilost, spol i trajanje bolesti

${ }^{\mathrm{b}}$ kriteriji za ulazak i izlazak nezavisne varijable iz regresijske jednadžbe: $\mathrm{F}$ za ulazak = 3,0, F za izlazak 1,0

Tablica 4. Koncentracije lipida u odnosu na trajanje bolesti i pretilost u muškaraca i žena

\begin{tabular}{|c|c|c|c|c|c|c|}
\hline & Zavisna varijabla & Nezavisna varijabla ${ }^{a}$ & b & Promjena $\mathbf{R}^{2}$ & $F^{b}$ & $P$ \\
\hline Muškarci (N = 64) & trigliceridi & pretilost & 0,29 & 0,083 & 4,34 & 0,043 \\
\hline \multirow[t]{4}{*}{ Žene ( $N=83$ ) } & ukupni kolesterol & pretilost & 0,31 & 0,096 & 5,21 & 0,027 \\
\hline & LDL kolesterol & pretilost & 0,37 & 0,138 & 7,82 & 0,008 \\
\hline & \multirow{2}{*}{ trigliceridi } & trajanje bolesti & 0,47 & 0,243 & 20,55 & $<0,001$ \\
\hline & & pretilost & 0,21 & 0,044 & 3,88 & 0,053 \\
\hline
\end{tabular}

a nezavisne varijable: pretilost i trajanje bolesti

${ }^{b}$ kriteriji za ulazak i izlazak nezavisne varijable iz regresijske jednadžbe: $F$ za ulazak = 3,0, F za izlazak 1,0 
Ipak, potrebno je spomenuti da su u našem istraživanju pretile pacijentice bile približno 3,5 godina starije u odnosu na nepretile (tablica 2), a trend prema starijoj dobi u pretilih ispitanika $u$ usporedbi s nepretilima zamijećen je i na ukupnom uzorku pacijenata u studiji provedenoj $u$ sjevernoameričkoj populaciji ${ }^{24}$. S druge strane, u dvije studije provedene u kineskoj populaciji uočen je veći rizik za pojavu pretilosti u žena u odnosu na muškarce; štoviše, u jednoj od studija učestalost pretilosti bila je čak dvostruko veća u žena negoli muškaraca $(31,8 \% \text { vs. } 15,8 \%)^{2,25}$. Navedena opažanja moguće je rastumačiti činjenicom da u starijoj dobi, posebice nakon menopauze, zbog smanjene proizvodnje estrogena, dolazi do povećanja količine abdominalnog (visceralnog) masnog tkiva, što pogoduje razvoju prekomjerne tjelesne mase i pretilosti ${ }^{25,38}$. Naime, među ispitanicima su najstariji bili upravo pacijenti iz kineske populacije u kojoj je srednja dob za ispitanike oba spola iznosila oko 52 godine, a što ukazuje da su pacijentice iz kineskih studija, u premenopauzi ili postmenopauzi. Nadalje, genetičke studije visoku stopu pretilosti u shizofreniji objašnjavaju činjenicom da bi shizofrenija, pretilost i metabolički sindrom mogli imati zajedničku genetičku podlogu ${ }^{19,21}$. Nastavno na navedeno, za očekivati je da bi pretilost, ali i ostali parametri metaboličkog sindroma, mogli biti udruženi s težom kliničkom slikom, a koja se, između ostalog, očituje ranijim nastupom bolesti. U skladu s time, nedavno je istraživanje u hrvatskoj populaciji ispitalo postoji li povezanost koncentracija kolesterola, triglicerida i glukoze u plazmi, te srednjih vrijednosti ITM-a, kao pokazatelja metaboličkog sindroma, s dobi nastupa shizofrenije ${ }^{39}$. Na temelju vrijednosti medijana dobi prve hospitalizacije za cijeli uzorak pacijenata, dob nastupa shizofrenije klasificirana je kao rana ( $\leq 26$ godina) i kasna (> 26 godina). Rezultati istraživanja tek djelomično podupiru moguću hipotezu o preklapanju genetičke etiologije shizofrenije i parametara metaboličkog sindroma. Ukratko, opažene su značajno više vrijednosti triglicerida u plazmi u muškaraca s ranijom dobi nastupa shizofrenije negoli u muškaraca s kasnim nastupom. S druge strane, koncentracije glukoze u plazmi u muškaraca s ranim nastupom shizofrenije bile su značajno više u odnosu na koncentracije glukoze $u$ muškaraca s kasnim nastupom bolesti, što proturječi hipotezi o preklapanju genetičke etiologije shizofrenije i metaboličkog sindroma. Konačno, nisu pronađene statistički značajne varijacije u srednjim vrijednostima ukupnog kolesterola, LDL kolesterola, HDL kolesterola i ITM-a s obzirom na dob nastupa bolesti, niti u pacijenata, niti u pacijentica. Nepostojanje povezanosti između ITM vrijednosti s dobi nastupa bolesti u spomenutom istraživanju ${ }^{39}$ zapravo dodatno podupire negativne rezultate ovog istraživanja koji impliciraju da godine dobi nastupa i trajanja bolesti ne pokazuju statistički značajne varijacije, ovisno o tome jesu li pacijenti pretili ili nisu (tablica 2).

Rezultati ovog istraživanja također upućuju na nepostojanje povezanosti simptoma ocjenske ljestvice PANSS-a s pojavom pretilosti (tablica 2), za razliku od rezultata studija provedenih u kineskoj populaciji u kojima je pronađena zanimljiva inverzna povezanost između pretilosti, odnosno, vrijednosti ITM-a, i težine kliničke simptomatologije shizofrenije ${ }^{2,25-27}$. Ukratko, opažene su značajno niže vrijednosti negativnih i ukupnih simptoma PANSS-a u pretilih muškaraca u odnosu na nepretile ${ }^{25}$, a studije na ukupnom uzorku pacijenata upućuju na značajno niže vrijednosti negativnih, općih i ukupnih simptoma u pacijenata s višim vrijednostima ITM-a ${ }^{2,26,27}$. Mehanizam protektivnog učinka pretilosti na težinu kliničke simptomatologije u shizofreniji mogao bi biti posljedica povišenih koncentracijama leptina koje su opažene $u$ mozgu pretilih pacijenata ${ }^{40}$. Leptin se, naime, smatra važnim modulatorom dopaminergičke neurotransmisije, a pri tome se poseban značaj pripisuje inhibitornom učinku leptina na pojačanu dopaminergičku aktivnost u prefrontalnom korteksu, budući da se ona povezuje s pozitivnim simptomima shizofrenije ${ }^{41,42}$. Nepostojanje povezanosti simptoma PANSS psihopatologije $s$ pojavom pretilosti, opaženo u ovom istraživanju, moglo bi, između ostalog, biti posljedica puno teže kliničke slike u naših pacijenata u odnosu na oboljele iz kineske populacije ${ }^{2,24-26}$. U skladu $\mathrm{s}$ time, moguće je da su pacijenti s težom kliničkom slikom slabije tjelesni aktivniji i skloniji nezdravim prehrambenim navikama, a što ne samo da pogoduje pojavi pretilosti, nego i umanjuje mogući protektivan učinak pretilosti na kliničku psihopatologiju, budući da je ona znatno lošija. Nadalje, 
nezdrave se prehrambene navike u pacijenata sa shizofrenijom, kao što je već spomenuto, odražavaju smanjenim unosom PUFA, posebice onih iz n-3 obitelji, a deficit PUFA kontinuirano je opažen u membranama živčanih stanica i eritrocita oboljelih ${ }^{43-48}$. Navedeno bi moglo biti važno u kliničkoj ekspresiji shizofrenije, budući da studije na animalnim modelima upućuju da deficit n-3 PUFA u membranama ima za posljedicu poremećenu membransku dinamiku na sinapsama i smanjenu ekspresiju dopaminskih receptora ${ }^{49-51}$. Konačno, neujednačenost rezultata koji se odnose na povezanost pojave pretilosti s težinom simptoma PANSS psihopatologije između naše studije i istraživanja provedenih u kineskoj populaciji mogla bi proizlaziti i iz razlika u etničkom podrijetlu. Istraživanja su pokazala da učestalost polimorfnih varijanti gena koji su implicirani u etiologiji shizofrenije i/ili pretilosti, posebice gena za neurotransmiterske sustave, pokazuje značajne varijacije među populacijama ${ }^{21,52,53}$.

Nepostojanje značajne razlike u učestalosti pojave pretilosti između pušača i nepušača uklapa se u rezultate nekih od studija koje su ispitale povezanost pojave pretilosti s pušenjem u shizofreni$\mathrm{ji}^{2,25,27}$. S druge strane, jedna studija provedena $u$ poljskih pacijenata sa shizofrenijom upućuje na značajno više vrijednosti ITM-a u pacijentica koje puše u odnosu na pacijentice koje ne puše ${ }^{54}$. Nadalje, istraživanja u općoj populaciji upućuju na značajno nižu učestalost prekomjerne tjelesne mase i pretilosti u pušača u odnosu na nepušače ${ }^{55,56}$; protektivan učinak pušenja proizlazi iz spoznaja da nikotin, glavna komponenta duhanskog dima koja dovodi do razvoja ovisnosti ${ }^{57}$, aktivira proopiomelanokortinske neuronalne signalne puteve, što dovodi do supresije apetita i povećanja potrošnje energije ${ }^{58,59}$. Navedeno implicira heterogenost odnosa između pušenja i pretilosti u pacijenata sa shizofrenijom, kao i na mogućnost da bi se odnos između pušenja i pretilosti mogao razlikovati u pacijenata sa shizofrenijom u odnosu na ispitanike koji ne boluju od psihičkih bolesti. Neujednačeni rezultati proizlaze i iz studija koje su istražile povezanost težine ovisnosti o pušenju, evaluirane kroz broj popušenih cigareta dnevno, s pojavom pretilosti2,25,60. Naime, u studijama u sjevernoameričkoj i kineskoj populaciji nije pronađena razlika u vrijednostima ITM-a između teških pušača (konzumiraju $\geq 20$ cigareta dnevno) i lakih pušača, kao niti razlika u broju popušenih cigareta između pretilih i nepretilih pacijenata ${ }^{25,60}$, dok jedna pak kineska studija implicira da bi veći broj popušenih cigareta dnevno ipak mogao pridonijeti smanjenom riziku za pojavu pretilosti².

Rezultati biokemijskih analiza u pretilih i nepretilih pacijenata pokazali su da su srednje vrijednosti triglicerida bile značajno više kod pretilih pacijenata oba spola, dok su vrijednosti ukupnog kolesterola i LDL kolesterola statistički značajno varirale ovisno o pojavi pretilosti isključivo u skupini pacijentica. Rezultati multiple regresijske analize na ukupnom uzorku pacijenata potvrdili su da je pretilost značajan prediktor vrijednosti kolesterola i triglicerida; dodatno, prediktorima koncentracije triglicerida pokazali su se spol i trajanje bolesti (tablica 3). S druge strane, analiza po spolu također je ukazala na povezanost pretilosti s koncentracijama ukupnog kolesterola i LDL kolesterola u žena i koncentracijama triglicerida u muškaraca (tablica 4). Ipak, kod pacijentica se trajanje bolesti pokazalo jedinim statistički značajnim prediktorom vrijednosti triglicerida, dok je učinak pretilosti na trigliceride ostao izvan granica statističke značajnosti. U svakom slučaju, doprinos pretilosti koncentracijama triglicerida $u$ muškaraca $(8,3 \%)$ te ukupnog kolesterola i LDL kolesterola u žena $(9,6 \%$ i $13,8 \%)$ smatramo zadovoljavajućim, a pozitivna povezanost povišenih lipida u plazmi i pojave pretilosti uklapa se u rezultate opisane u literaturi. Naime, studije nedavno provedene u kineskoj populaciji ukazuju na više vrijednosti triglicerida, ukupnog kolesterola i LDL kolesterola u pretilih ispitanika i pacijenata $\mathrm{s}$ višim vrijednostima ITM-a $a^{2,25-27}$. Nadalje, studija provedena na sjevernoameričkom uzorku pacijenata, a koja je, osim pacijenata sa shizofrenijom i shizoafektivnim poremećajem, uključila oboljele od bipolarnog afektivnog poremećaja, pronalazi značajno veću učestalost dislipidemija u pretilih pacijenata ${ }^{24}$. Inače, zanimljivo je da većina studija upućuje na pozitivnu povezanost koncentracije glukoze u plazmi i/ili rizika za obolijevanje od dijabetesa tipa 2, s pojavom pretilosti2,24,25,27. lako je povezanost pretilosti, inzulinske rezistencije i metaboličkog sindroma dobro poznata u literaturi61,62, rezultati naše studije upućuju na nepostojanje značajnih varijacija u srednjim koncentracijama 
glukoze, ovisno o pojavi pretilosti (tablica 2). Spekuliramo da bi nepostojanje statistički značajne povezanosti između pojave pretilosti i koncentracija glukoze u plazmi moglo proizlaziti iz činjenice da su u našem uzorku ispitanika vrijednosti glukoze u svim testiranim skupinama, s izuzetkom blago povišenih vrijednosti u pretilih žena, odgovarale vrijednostima za zdrave ispitanike, odnosno, nalazile se unutar referentnih vrijednosti za opću populaciju Republike Hrvatske (tablice 1 i 2$)^{36,37}$. Nadalje, mišljenja smo da bi slična spoznaja mogla objasniti negativne rezultate za HDL kolesterol i pretilost (tablice 1 i 2), a također je potrebno spomenuti da je nepostojanje statistički značajnih varijacija u koncentracijama HDL kolesterola, ovisno o pojavi pretilosti, u skladu s mnogim negativnim rezultatima u literaturi ${ }^{i 2,24-26}$. Rezultati našeg istraživanja impliciraju zanimljivu mogućnost da bi se odnos između pretilosti i koncentracija specifičnih lipida u plazmi (trigliceridi, ukupni kolesterol i LDL kolesterol) mogao donekle razlikovati u pacijenata sa shizofrenijom u odnosu na ispitanike koji ne boluju od psihičkih bolesti. Naime, pokazali smo da su trigliceridi statistički značajan prediktor koncentracija triglicerida isključivo u muškaraca (tablica 4), dok kineska studija provedena na velikom uzorku kardioloških i drugih kroničnih pacijenata ( $N=16340)$ upućuje na postojanje statistički značajne povezanosti između ITM vrijednosti i koncentracija triglicerida među ispitanicima oba spola ${ }^{63}$. Nadalje, istraživanje provedeno u općoj španjolskoj populaciji ukazuje na izraženiju povezanost vrijednosti ITM-a s koncentracijama ukupnog kolesterola i LDL kolesterola u muškaraca negoli u žena, dok su u našoj studiji vrijednosti ukupnog kolesterola i LDL kolesterola pokazale povezanost s pojavom pretilosti isključivo u žena (tablica 4$)^{64}$. Navedene razlike moguće je, između ostalog, pripisati činjenici da pojavu pretilosti u oboljelih od shizofrenije dodatno moduliraju okolišni čimbenici, poput antipsihotika i nezdrave prehrane ${ }^{3,4}$. Inače, istraživanja upućuju na mogući doprinos antipsihotika poremećenom metabolizmu lipida i glukoze koji je neovisan o njihovom učinku na porast tjelesne mase ${ }^{4,65-67}$. Jedan od mehanizama mogao bi biti posredovan indukcijom ekspresije gena za transkripcijske čimbenike, poput gena za protein koji veže regulacijski element sterola (engl. Sterol regulatory element-binding protein - SREBP), gena za peroksisomnim proliferatorom aktivirani receptor gama (engl. Peroxisome proliferator-activated receptor gamma - PPAR $)$, kao i gena za enzim lipoproteinsku lipazu, čija se pojačana ekspresija povezuje s razvojem masne jetre, inzulinske rezistencije, dislipidemija i dr. ${ }^{4,65,67}$ Zanimljive studije na animalnim modelima također upućuju da pojedini antipsihotici mogu inhibirati sekreciju inzulina iz beta-stanica gušterače te pospješiti proces glikogenolize $u$ jetri ${ }^{61,68,69}$, a uočen je i inhibitorni učinak antipsihotika na funkciju transportera glukoze (engl. Glucose transporters - GLUT) u jetri, gušterači i crijevnom epitelu ${ }^{66,70}$. Ipak, čini se da niti rezultati studija koje su istražile biokemijske korelate pretilosti u oboljelih od shizofrenije nisu ujednačeni, a tome bi, osim izloženosti okolišnim čimbenicima, mogle pridonijeti razlike u obilježjima uzorka ispitanika. Primjerice, jedna je kineska studija ispitala fenomen pretilosti zasebno u pacijenata i pacijentica sa shizofrenijom i pronašla je povezanost pretilosti s koncentracijama triglicerida među ispitanicima oba spola, a ne samo u pacijenata, kao što je to bio slučaj u ovom istraživanju ${ }^{24}$. Veća učestalost pretilosti i starija dob ispitanica, opaženi u kineskoj studiji, pogoduju razvoju prekomjerne tjelesne mase i pretilosti i mogli bi, prema našem mišljenju, objasniti razlike u rezultatima između našeg i kineskog istraživanja ${ }^{25,38}$.

Istraživanje provedeno u kineskoj populaciji na kardiološkim i drugim kroničnim pacijentima implicira da pozitivna povezanost koncentracija triglicerida u plazmi s vrijednostima ITM-a postaje jača paralelno s porastom ITM- $\mathrm{a}^{63}$. Nastavno na navedeno, nije isključivo da povezanost biokemijskih parametara s pojavom pretilosti postaje izraženija pri višim vrijednostima biokemijskih parametara. U prilog tome svjedoče naši rezultati koji upućuju da su vrijednosti triglicerida, koje su u našem istraživanju pokazale povezanost s pojavom pretilosti u muškaraca (tablice 2 i 4), bile statistički značajno više u muškaraca (tablica 1 ). Nadalje, vrijednosti ukupnog kolesterola i LDL kolesterola koje su pokazale statistički značajnu povezanost s pojavom pretilosti u žena (tablice $2 \mathrm{i}$ 4), također su bile više u žena (tablica 1 ). 
Mali uzorak ispitanika, nepostojanje kontrolne skupine, nedostatak anamnestičkih podataka o specifičnim antipsihoticima koje su pacijenti uzimali, kao i nedostatak podataka o prehrambenim navikama oboljelih, uz činjenicu da su u istraživanju sudjelovali isključivo kronični pacijenti, koji su zbog težine kliničke slike hospitalizirani, predstavljaju važne nedostatke ove studije. Preciznija evaluacija prekomjerne tjelesne mase i pretilosti (određivanje postotka masnog tkiva, mjerenje opsega struka i omjera opsega struka i bokova, bioelektrična impedancijska analiza i dr. $)^{71}$, uz izdvajanje pacijenata s prekomjernom tjelesnom masom kao zasebne kategorije ispitanika mogli bi biti od važnosti u istraživanjima koja će uslijediti. Nadalje, bilo bi zanimljivo, povezano s pojavom pretilosti, ispitati veći broj kliničkih parametara shizofrenije (primjerice, depresivne simptome, kognitivne funkcije oboljelih i dr.), ali i neke demografske značajke, poput stupnja obrazovanja, bračnog statusa, socioekonomskog statusa i dr. Zaključno, naši rezultati podupiru literaturne spoznaje koje upućuju da su pretili pacijenti sa shizofrenijom na terapiji antipsihoticima značajno skloniji razvoju dislipidemija. Pri tome je rizik za pojavu dislipidemija u pretilih pacijenata ovisan o spolu; u muškaraca je pretilost prvenstveno rizičan čimbenik za hipertrigliceridemiju, a u žena za hiperkolesterolemiju. Pojava pretilosti opisuje približno $8,3 \%$ varijabilnosti koncentracije triglicerida u muškaraca te 9,6 \% i 13,8 \% varijabilnosti koncentracije ukupnog kolesterola i LDL kolesterola u žena. U ovom smo istraživanju, također, pokazali da pretilost nije povezana s dobi, dobi nastupa bolesti i pojavom ovisnosti o pušenju te da ne djeluje protektivno na težinu ocjenske ljestvice PANSS-a, kao što upućuju literaturni podaci za druge populacije (kineska populacija). Nepostojanje statistički značajne povezanosti pojave pretilosti sa simptomima ocjenske ljestvice PANSS-a ukazuje na potrebu daljnjeg ispitivanja odnosa između pretilosti i kliničke manifestacije shizofrenije. Konačno, snaga ovog istraživanja dodatno proizlazi iz činjenica da smo sve analizirane podatke prikazali za muškarce i žene, što u većini studija nije bio slučaj ${ }^{62,23,24,26,27}$, kao i da je istraživanje napravljeno na etnički, ali i geografski homogenom populacijskom uzorku (sjeverno Hrvatsko primorje).
Ovo istraživanje poticano je sredstvima potpora 13.06.1.3.39, 17.07.2.1.10 i uniri-biomed-18-251 koja je odobrilo Sveučilište u Rijeci.

Izjava o sukobu interesa: Autori izjavljuju da ne postoji sukob interesa.

\section{LITERATURA}

1. de Hert M, Schreurs V, Vancampfort D, van Winkel R. Metabolic syndrome in people with schizophrenia: a review. World Psychiatry 2009;8:15-22.

2. Li Q, Du X, Zhang Y, Yin G, Zhang G, Walss-Bass $C$ et al. The prevalence, risk factors and clinical correlates of obesity in Chinese patients with schizophrenia. Psychiatry Res 2017;251:131-6.

3. McElroy SL. Obesity in patients with severe mental illness: overview and management. J Clin Psychiatry 2009;70:3:12-21.

4. Rojo LE, Gaspar PA, Silva H, Risco L, Arena P, Cubillos-Robles $\mathrm{K}$ et al. Metabolic syndrome and obesity among users of second generation antipsychotics: A global challenge for modern psychopharmacology. Pharmacol Res 2015;101:74-85.

5. Panariello F, De Luca V, de Bartolomeis A. Weight gain, schizophrenia and antipsychotics: new findings from animal model and pharmacogenomic studies. Schizophr Res Treatment 2011; doi: 10.1155/2011/459284.

6. Dipasquale S, Pariante CM, Dazzan P, Aguglia E, McGuire $\mathrm{P}$, Mondelli V. The dietary pattern of patients with schizophrenia. J Psychiatr Res 2013;197-207.

7. Ventriglio A, Gentile A, Stella E, Bellomo A. Metabolic issues in patients affected by schizophrenia: clinical characteristics and medical management. Front Neurosci 2015; doi: 10.3389/fnins.2015.00297.

8. Reynolds GP, Kirk SL. Metabolic side effects of antipsychotic drug treatment--pharmacological mechanisms. Pharmacol Ther 2010;125:169-79.

9. Fernø J, Varela L, Skrede S, Vázquez MJ, Nogueiras R, Diéguez $C$ et al. Olanzapine-induced hyperphagia and weight gain associate with orexigenic hypothalamic neuropeptide signaling without concomitant AMPK phosphorylation. PLoS One 2011; doi: 10.1371/journal. pone.0020571.

10. Šarić M, Škunca M, Ortner Hadžiabdić M, Božikov V. Metabolički sindrom - novi pristup u definiranju i liječenju. Farmaceutski glasnik 2013;69:333-45.

11. Stepien M, Stepien A, Wlazel RN, Paradowski M, Rizzo $M$, Banach $M$ et al. Predictors of insulin resistance in patients with obesity: a pilot study. Angiology 2014;65:2230.

12. Kucerova J, Babinska Z, Horska K, Kotolova H. The common pathophysiology underlying the metabolic syndrome, schizophrenia and depression. A review. Biomed Pap Med Fac Univ Palacky Olomouc Czech Repub 2015;159:208-14.

13. Ellulu MS, Patimah I, Khaza'ai H, Rahmat A, Abed Y. Obesity and inflammation: the linking mechanism and the complications. Arch Med Sci 2017;13:851-63.

14. Henderson DC, Borba CP, Daley TB, Boxill R, Nguyen DD, Culhane MA et al. Dietary intake profile of patients with schizophrenia. Ann Clin Psychiatry 2006;99-105. 
15. Amani R. Is dietary pattern of schizophrenia patients different from healthy subjects? BMC Psychiatry 2007;7:15.

16. Buretić-Tomljanović A, Giacometti J, Nadalin S, Rubesa G, Vulin M, Tomljanović D. Phospholipid membrane abnormalities and reduced niacin skin flush response in schizophrenia. Psychiatr Danub 2008;20:372-83.

17. Vassiliou EK, Gonzalez A, Garcia C, Tadros JH, Chakraborty $\mathrm{G}$, Toney JH. Oleic acid and peanut oil high in oleic acid reverse the inhibitory effect of insulin production of the inflammatory cytokine TNF-alpha both in vitro and in vivo systems. Lipids Health Dis 2009;8:25. doi: 10.1186/1476-511X-8-25.

18. Teng KT, Chang CY, Chang LF, Nesaretnam K. Modulation of obesity-induced inflammation by dietary fats: mechanisms and clinical evidence. Nutr J 2014;doi: 10.1186/1475-2891-13-12.

19. Manu P, Dima L, Shulman M, Vancampfort D, De Hert M, Correll CU. Weight gain and obesity in schizophrenia: epidemiology, pathobiology, and management. Acta Psychiatr Scand 2015;132:97-108.

20. Storch Jakobsen A, Speyer H, Nørgaard HCB, Hjorthøj C, Krogh J, Mors $\mathrm{O}$ et al. Associations between clinical and psychosocial factors and metabolic and cardiovascular risk factors in overweight patients with schizophrenia spectrum disorders - Baseline and two-years findings from the CHANGE trial. Schizophr Res. 2018;199:96-102.

21. Malan-Müller S, Kilian S, van den Heuvel LL, Bardien S, Asmal $L$, Warnich $L$ et al. A systematic review of genetic variants associated with metabolic syndrome in patients with schizophrenia. Schizophr Res 2016;170:1-17.

22. Sagud $M$, Mihaljević-Peles A, Mück-Seler D, Pivac $N$, Vuksan-Cusa B, Brataljenović T et al. Smoking and schizophrenia. Psychiatr Danub 2009;21:371-5.

23. Guo X, Zhang Z, Wei Q, Lv H, Wu R, Zhao J. The relationship between obesity and neurocognitive function in Chinese patients with schizophrenia. BMC Psychiatry 2013;13:109. doi: 10.1186/1471-244X-13-109.

24. Chouinard VA, Pingali SM, Chouinard G, Henderson DC, Mallya SG, Cypess AM et al. Factors associated with overweight and obesity in schizophrenia, schizoaffective and bipolar disorders. Psychiatry Res 2016;237:304-10.

25. Li Q, Chen D, Liu T, Walss-Bass C, de Quevedo JL, Soares $\mathrm{JC}$ et al. Sex differences in body mass index and obesity in Chinese patients with chronic schizophrenia. J Clin Psychopharmacol 2016;36:643-8.

26. An H, Du X, Huang X, Qi L, Jia Q, Yin G et al. Obesity, altered oxidative stress, and clinical correlates in chronic schizophrenia patients. Transl Psychiatry 2018; doi: 10.1038/s41398-018-0303-7.

27. Tian Y, Liu D, Wang D, Wang J, Xu H, Dai Q et al. Obesity in Chinese patients with chronic schizophrenia: Prevalence, clinical correlates and relationship with cognitive deficits. Schizophr Res 2019; doi: 10.1016/j.schres.2019. 10.017 .

28. Vlatković $S$, Živković $M$, Šagud $M$, Mihaljević-Peleš A. Metabolički sindrom u shizofreniji: prepoznavanje i mogućnosti prevencije. Soc psihijat 2014;42:114-22.

29. Nadalin S, Buretić-Tomljanović A, Rebić J, Pleša I, Šendula Jengić V. An association between the PPAR $\alpha-L 162 \mathrm{~V}$ polymorphism and nicotine dependency among patients with schizophrenia. Compr Psychiatry 2016;70:118-24.

30. Nikolac M, Sagud M, Nedic G, Nenadic Sviglin K, Mihaljevic Peles $A$, Uzun $S$ et al. The lack of association between
catechol-O-methyl-transferase Val108/158Met polymorphism and smoking in schizophrenia and alcohol dependence. Psychiatry Res 2013;205:179-80.

31. Kay SR, Fiszbein A, Opler LA. The positive and negative syndrome scale (PANSS) for schizophrenia. Schizophr Bull 1987;13:261-76.

32. de Leon J, Diaz FJ. A meta-analysis of worldwide studies demonstrates an association between schizophrenia and tobacco smoking behaviors. Schizophr Res 2005;76:135-57.

33. Guo S, Chen DF, Zhou DF, Sun HQ, Wu GY, Haile CN et al. Association of functional catechol O-methyl transferase (COMT) Val108Met polymorphism with smoking severity and age of smoking initiation in Chinese male smokers. Psychopharmacology (Berl) 2007;190:449-56.

34. Fišter K, Vuletić S, Kern J. Paving the way for personalised behaviourally based prevention of obesity: systematic search of the literature. Coll Antropol 2012;36: 201-10.

35. Milanović SM, Ivanković D, Uhernik Al, Fister K, Peternel $\mathrm{R}$, Vuletić S. Obesity - new threat to Croatian longevity. Coll Antropol 2012;3:113-6.

36. Bergman-Marković B, Maltar-Delija S. Metabolički sindrom u obiteljskoj medicini. Medix - Specijalizirani medicinski dvomjesečnik 2006;65:139-40.

37. Bergovec $M$, Reiner Z, Milicić D, Vrazić $H$. Differences in risk factors for coronary heart disease in patients from continental and Mediterranean regions of Croatia. Wien Klin Wochenschr 2008;120:684-92.

38. Lizcano F, Guzmán G. Estrogen deficiency and the origin of obesity during menopause. Biomed Res Int 2014; doi: 10.1155/2014/757461.

39. Nadalin S, Rebić J, Ružić K, Buretić-Tomljanović A. The relationship between components of metabolic syndrome and disease onset in patients with schizophrenia. Schizophr Res 2018;201:420-1.

40. Potvin S, Zhornitsky S, Stip E. Antipsychotic-induced changes in blood levels of leptin in schizophrenia: a meta-analysis. Can J Psychiatry 2015;60:S26-34.

41. Takayanagi Y, Cascella NG, Santora D, Gregory PE, Sawa A, Eaton WW. Relationships between serum leptin level and severity of positive symptoms in schizophrenia. Neurosci Res 2013;77:97-101.

42. Nurjono M, Neelamekam S, Lee J. Serum leptin and its relationship with psychopathology in schizophrenia. Psychoneuroendocrinology 2014;50:149-54.

43. Yao JK, Leonard S, Reddy RD. Membrane phospholipid abnormalities in postmortem brains from schizophrenic patients. Schizophr Res 2000;42:7-17.

44. Reddy RD, Keshavan MS, Yao JK. Reduced red blood cell membrane essential polyunsaturated fatty acids in first episode schizophrenia at neuroleptic-naive baseline. Schizophr Bull 2004;30:901-11.

45. McNamara RK, Jandacek R, Rider T, Tso P, Hahn CG, Richtand NM et al. Abnormalities in the fatty acid composition of the postmortem orbitofrontal cortex of schizophrenic patients: gender differences and partial normalization with antipsychotic medications. Schizophr Res 2007;91:37-50.

46. Sumiyoshi T, Matsui M, Itoh H, Higuchi $\mathrm{Y}$, Arai H, Takamiya $C$ et al. Essential polyunsaturated fatty acids and social cognition in schizophrenia. Psychiatry Res 2008; 157:87-93. 
47. van der Kemp WJ, Klomp DW, Kahn RS, Luijten PR, Hulshoff Pol HE. A meta-analysis of the polyunsaturated fatty acid composition of erythrocyte membranes in schizophrenia. Schizophr Res 2012;141:153-61.

48. Nadalin S, Giacometti J, Jonovska S, Tomljanović D, Buretić-Tomljanović A. The impact of PLA2G4A and PTGS2 gene polymorphisms, and red blood cell PUFAs deficit on niacin skin flush response in schizophrenia patients. Prostaglandins Leukot Essent Fatty Acids 2013;88:185-90.

49. Zimmer L, Delion-Vancassel S, Durand G, Guilloteau D, Bodard S, Besnard JC, Chalon S Modification of dopamine neurotransmission in the nucleus accumbens of rats deficient in $\mathrm{n}-3$ polyunsaturated fatty acids. J Lipid Res 2000;41:32-40.

50. Ohara K. The $n-3$ polyunsaturated fatty acid/dopamine hypothesis of schizophrenia. Prog Neuropsychopharmacol Biol Psychiatry 2007;31:469-74.

51. Fedorova I, Hussein N, Baumann MH, Di Martino C, Salem N Jr. An n-3 fatty acid deficiency impairs rat spatial learning in the Barnes maze. Behav Neurosci 2009;123:196-205.

52. Wiers $C E$, Towb PC, Hodgkinson $C A$, Shen PH, Freeman $C$, Miller $G$ et al. Association of genetic ancestry with striatal dopamine D2/D3 receptor availability. Mol Psychiatry 2018;23:1711-6.

53. Li J, Hashimoto H, Meltzer HY. Association of serotonin2c receptor polymorphisms with antipsychotic drug response in schizophrenia. Front Psychiatry 2019; doi: 10.3389/fpsyt.2019.00058.

54. Wójciak RW, Stanisławska-Kubiak $M$, Skommer $M$, Nowogrodzka A. The occurrence of tobacco smoking and obesity in schizophrenia women. Przegl Lek 2009; 66:733-5.

55. Chhabra P, Chhabra SK. Effect of smoking on body mass index: a community-based study. Natl J Community Med 2011;2:325-30.

56. Dare S, Mackay DF, Pell JP. Relationship between smoking and obesity: a cross-sectional study of 499,504 middle-aged adults in the UK general population. PLoS One 2015;10:e0123579.

57. Dani JA. Roles of dopamine signaling in nicotine addiction. Mol Psychiatry 2003;8:255-6.

58. Chiolero A, Faeh D, Paccaud F, Cornuz J. Consequences of smoking for body weight, body fat distribution, and insulin resistance. Am J Clin Nutr 2008;87:801-9.

59. Mineur YS, Abizaid A, Rao Y, Salas R, DiLeone RJ, Gündisch $D$ et al. Nicotine decreases food intake through activation of POMC neurons. Science 2011;332:1330-2.
60. Wehring HJ, Liu F, McMahon RP, Mackowick KM, Love $R C$, Dixon $L$ et al. Clinical characteristics of heavy and non-heavy smokers with schizophrenia. Schizophr Res 2012;138:285-9.

61. Kahn SE, Hull RL, Utzschneider KM. Mechanisms linking obesity to insulin resistance and type 2 diabetes. Nature. 2006;444:840-6.

62. Barazzoni R, Gortan Cappellari G, Ragni M, Nisoli E. Insulin resistance in obesity: an overview of fundamental alterations. Eat Weight Disord 2018;23:149-57.

63. Zhang A, Yao Y, Xue Z, Guo X, Dou J, Lv Y et al. A study on the factors influencing triglyceride levels among adults in Northeast China. Sci Rep 2018; doi: 10.1038/s41598018-24230-4.

64. Schröder H, Marrugat J, Elosua R, Covas MI; REGICOR Investigators. Relationship between body mass index, serum cholesterol, leisure-time physical activity, and diet in a Mediterranean Southern-Europe population. $\mathrm{Br} \mathrm{J}$ Nutr 2003;90:431-9.

65. Qi NR, Wang J, Zidek V, Landa V, Mlejnek P, Kazdová L et al. A new transgenic rat model of hepatic steatosis and the metabolic syndrome. Hypertension 2005;45:100411.

66. Arulmozhi DK, Dwyer DS, Bodhankar SL. Antipsychotic induced metabolic abnormalities: an interaction study with various PPAR modulators in mice. Life Sci 2006; 79:1865-72

67. Yang Z, Yin JY, Gong ZC, Huang $Q$, Chen $\mathrm{H}$, Zhang $\mathrm{W}$ et al. Evidence for an effect of clozapine on the regulation of fat-cell derived factors. Clin Chim Acta 2009;408:98104.

68. Johnson DE, Yamazaki H, Ward KM, Schmidt AW, Lebel WS, Treadway JL et al. Inhibitory effects of antipsychotics on carbachol-enhanced insulin secretion from perifused rat islets: role of muscarinic antagonism in antipsychotic-induced diabetes and hyperglycemia. Diabetes 2005;54:1552-8.

69. Hampson LJ, Mackin P, Agius L. Stimulation of glycogen synthesis and inactivation of phosphorylase in hepatocytes by serotonergic mechanisms, and counter-regulation by atypical antipsychotic drugs. Diabetologia. 2007;50:1743-51.

70. Nasrallah HA, Newcomer JW. Atypical antipsychotics and metabolic dysregulation: evaluating the risk/benefit equation and improving the standard of care. J Clin Psychopharmacol 2004;24:S7-14.

71. Wells JC, Fewtrell MS. Measuring body composition. Arch Dis Child 2006;91:612-7. 